\title{
УДК 624.21:[625.1:625.141-048.78]
}

\author{
С. М. ДЕМЧЕНКО ${ }^{1}$, А. М. КУРГАН ${ }^{2}$, Г. О. ЛИННИК ${ }^{3 *}$ \\ ${ }^{1}$ Структурний підрозділ «Дніпровське науково-конструкторське технологічне бюро колійного господарства» \\ філії «Науково-дослідний та конструкторсько-технологічний інститут залізничного транспорту» АТ «Укрзалізниця», \\ пл. Вокзальна 11-Ж, м. Дніпро, Україна, 49000, тел. +38 (056) 79323 60, ел. пошта s.demchenko@dp.uz.gov.ua \\ ${ }^{2}$ Структурний підрозділ «Дніпровське науково-конструкторське технологічне бюро колійного господарства» \\ філії «Науково-дослідний та конструкторсько-технологічний інститут залізничного транспорту» АТ «Укрзалізниця», \\ пл. Вокзальна 11-Ж, м. Дніпро, Україна, 49000, тел. +38 (056) 79323 47, ел. пошта a.kurgan@dp.uz.gov.ua \\ $3^{*}$ Департамент колії та споруд АТ «Укрзалізниця», вул. Є. Гедройця, 5, м. Київ, Україна, 03150, тел. +38 (044) 4650354 , \\ ел пошта georgiylinnik@gmail.com
}

\section{УДОСКОНАЛЕННЯ ТЕХНОЛОГІї УКЛАДАННЯ БЕЗБАЛАСТНОГО МОСТОВОГО ПОЛОТНА НА ЗАЛІЗНИЧНИХ МОСТАХ}

Мета. Удосконалення технології укладання безбаластного мостового полотна на плитах БМП шляхом заміни дерев'яних прокладок на швидкотвердіючі високоміцні підливні суміші з установкою плит у проєктне положення з використанням спеціальних регулюючих пристроїв. Методика. Запропонований авторами регулюючий пристрій, що складається з болта типу БР та закладної деталі, яка входить до складу плити безбаластного мостового полотна. Пристрій забезпечує встановлення плити БМП у проєктне положення по вертикалі з точністю \pm 1 мм та витримує навантаження від власної ваги й рухомого складу, що застосовується під час укладання та рихтовки мостового полотна. Для лабораторних випробувань була розроблена схема i побудований стенд, який дозволяє відповідно до вимог У 7012.02.000 ПМ (2012), здійснювати навантаження на плиту БМП-КРм, встановлену на регулюючі болти типу БР. Навантаження забезпечувалось гідравлічною системою і передавалось на плиту через змонтовані на плиті колійні рейки, прикладалось у двох точках на кожну рейку симетрично відносно поздовжньої вісі. Випробування проводились до руйнування. Результати. При навантажені 137 кН на одну точку сталась втрата стійкості регулюючих болтів типу БР. Використана незнімна опалубка та швидкотвердіюча безусадочна суміш замість прокладних брусів у взаємодії з болтами регулюючими типу БР. Наукова новизна. Вона полягає в отриманні залежностей зусиль від конструкції БМП. Практична значимість. Підтверджена відповідність дослідних зразків плит типу БМП-КРм з елементами регулювання їх проєктного положення вимогам конструкторської та технічної документації.

Ключові слова: безбаластне мостове полотно; болт регулюючий; регулюючий пристрій; шпилька високоміцна; прокладний шар; швидкотвердіюча суміш; випробування

\section{Вступ}

Сучасне залізничне сполучення неможливо уявити без високих швидкостей як основи інноваційного розвитку залізниць. В даний час на магістралях світу використовуються дві принципово різні конструкції залізничної колії: традиційна залізнична колія на баласті і безбаластна.

Під терміном безбаластна колія поєднується декілька доволі різноманітних конструкційних рішень. Суттєва різниця полягає в конструкції підрейкової основи: це може бути колія на окремих опорах (на шпалах, напівшпалах або спеціальних блоках) та на безперервній основі у вигляді плит.

(C) С. М. Демченко, А. М. Курган, Г. О. Линник, 2020
Особливої уваги в плані еволюції конструкції залізничної колії заслуговує приклад Японії. 3 огляду на сприятливі топографічні умови, на більшій частині магістралі (54 \%) була застосована класична будова залізничної колії - на земляному полотні. Інша ж частина лінії (46 \%) розміщувалася на тих чи інших штучних спорудах. На поточне утримання ділянок колії, що була укладена на жорсткій основі, витрати виявилися в 3...5 разів меншими. Ці обставини сприяли тому, що надалі було зроблено вибір на користь жорсткої основи конструкції колії.

Безбаластне мостове полотно на залізобетонних плитах широко застосовують на металевих залізничних мостах (рис. 1) (Ключник, 2017). 


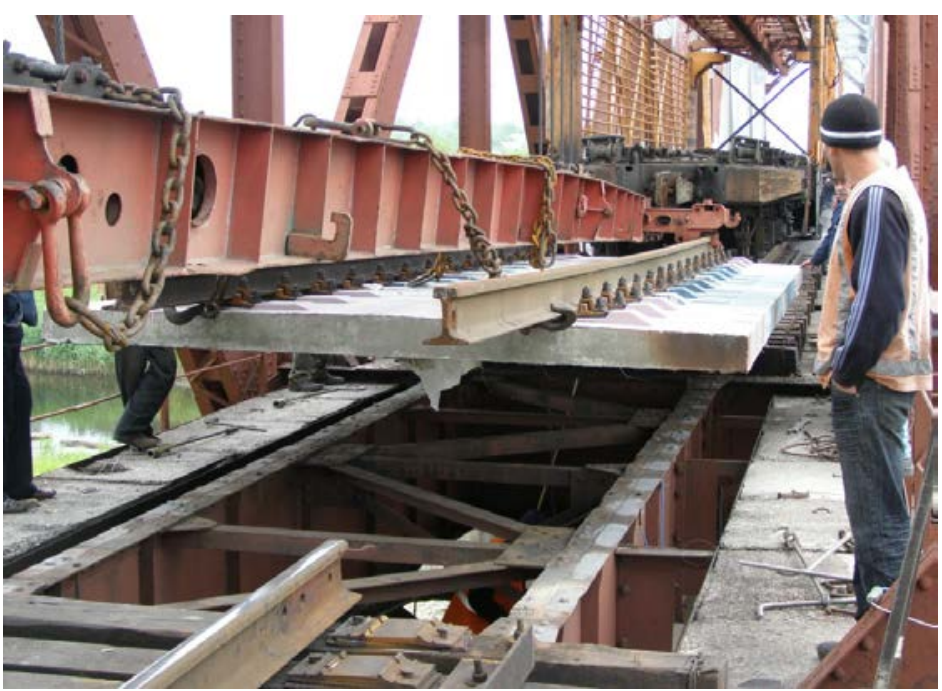

Рис. 1. Укладання мостового полотна на плитах БМП

Воно має високу стабільність положення елементів і тривалий термін використання, захищає від забруднення і корозії верхні пояси балок і в'язі між ними, дає можливість заміняти мостове полотно на дерев'яних поперечинах без зміни відмітки колії на мосту та підходах, створює безпечний прохід мостом колісних пар у випадку сходу з рейок, $є$ економічним за сумарною вартістю виготовлення, укладання та експлуатації протягом усього терміну служби мосту в порівнянні $з$ типовим мостовим полотном на дерев'яних поперечинах (Марочка, \& Бобошко, 2018; Marochka, \& Boboshko, 2018).

На залізничних мостах АТ «Укрзалізниця» експлуатується більше 25 км мостового полотна на дерев’яних брусах, які у плановому порядку потребують заміни на залізобетонні плити. Існуюча технологія укладання безбаластного мостового полотна на залізобетонних плитах трудомістка, для реалізації вимагає значних за часом технологічних вікон і тому потребуе удосконалення. У теперішній час у якості прокладного шару, через який залізобетонні плити безбаластного мостового полотна (далі - плита БМП) з'єднують 3 поздовжніми балками прогонової будови мосту використовують прокладки з твердих порід дерева, (переважно дубові) та пластини з гумовокордової транспортерної стрічки товщиною 8...10 мм. Однак, з досвіду експлуатації такої конструкції відомо, що використання дерев'яних прокладок має ряд недоліків: неможливість досягнення проєктної точності укладання плит типу БМП ( \pm 1 мм); значні трудовитрати на виготовлення прокладок, зважаючи на те, що практично кожна прокладка має індивідуальні розміри, потребує відповідного маркування; вимагає значних трудовитрат на підгонку прокладок «по місцю» у місцях зміни товщини верхнього горизонтального листа поздовжніх балок, розміщення «рибок», стикових накладок, заклепок, високоміцних болтів. Крім того, навіть антисептовані прокладки 3 твердих порід деревини мають проєктний термін служба не більше $10 \ldots 15$ років, що втричі менше строку служби плит.

\section{Мета}

3 урахуванням вище перелічених недоліків, було встановлено, що технологія укладання безбаластного мостового полотна на плитах БМП та конструкція прокладного шару потребує удосконалення. Вирішення вищезазначеної проблеми можливо шляхом заміни дерев’яних прокладок на швидкотвердіючі високоміцні підливні суміші з установкою плит у проєктне положення з використанням спеціальних регулюючих пристроїв.

\section{Методика}

Роботи щодо удосконалення технології укладання безбаластного мостового полотна на залізничних мостах виконувались у тісній співпраці працівників СП «Дніпровське НКТБ КГ» філії «НДКТІ» АТ «Укрзалізниця», філії «Старокостянтинівський завод залізобетонних

(C) С. М. Демченко, А. М. Курган, Г. О. Линник, 2020 
МОСТИ ТА ТУНЕЛІ: ТЕОРІЯ, ДОСЛІДЖЕННЯ, ПРАКТИКА

шпал» та фахівцями Департаменту колії та споруд АТ «Укрзалізниця».

Для досягнення поставленої мети, на попередньому етапі були визначені основні вимоги до регулюючого пристрою. Встановлено, що такий пристрій повинен:

- відповідати вимогам інструкції ЦП-0137 (2006) та існуючих проєктів укладання плит безбаластного мостового полотна;

- забезпечувати встановлення плити БМП у проєктне положення по вертикалі з точністю \pm 1 мм та витримувати навантаження від власної ваги й рухомого складу, що застосовується під час укладання та рихтовки мостового полотна;

- забезпечувати при встановленні плити у проєктне положення зазор між верхом поздовжньої балки та нижньою гранню плити у межах від 20 до 75 мм. Додатково були враховані складність та вартість виготовлення складових частин регулюючого пристрою, його взаємодію 3 існуючою плитою типу БМП та ін.

Запропонований авторами регулюючий пристрій складається з болта типу БР (далі - болт) (рис. 2) та закладної деталі (рис. 3), яка входить до складу плити безбаластного мостового полотна.
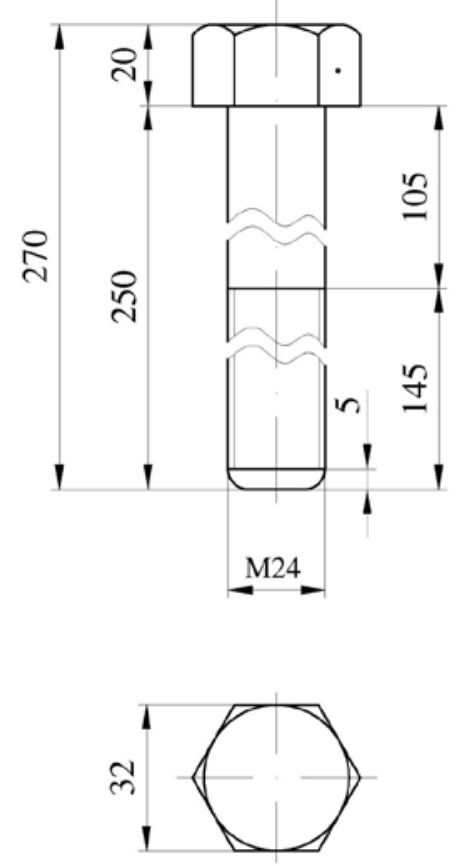

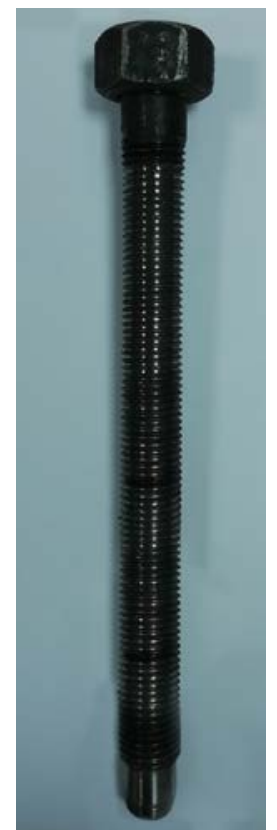

Рис. 2. Болт регулюючий типу БР

Регулюючий болт виготовляють зі сталі 45 за ГОСТ 1050-2013 (2013) довжиною 270 мм, яка забезпечує можливість встановлення плити у проєктне положення та надає змогу розміщення опалубки для заливки швидкотвердіючої безусадочної суміші.
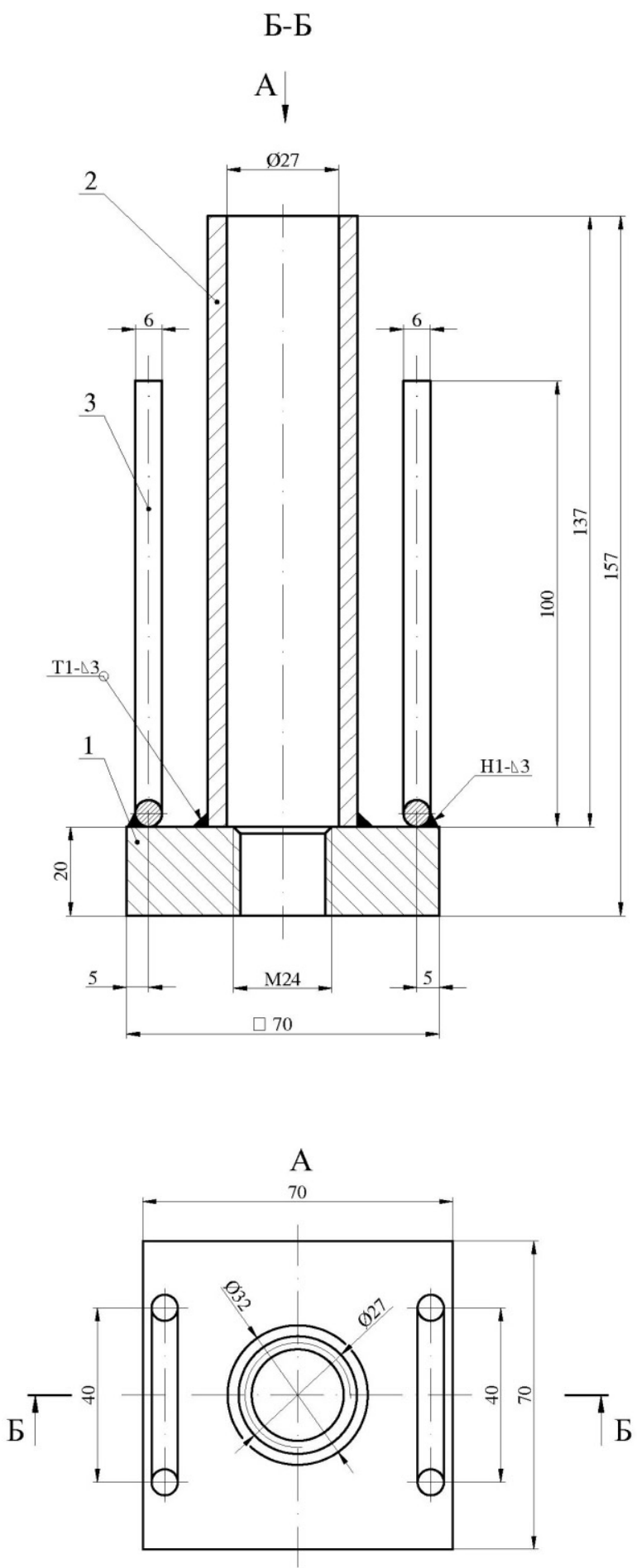

Рис. 3. Закладна деталь:

1 - шайба опорна; 2 - труба $25 \times 3,5$ мм; 3 - стрижень $\varnothing 6$ мм

(C) С. М. Демченко, А. М. Курган, Г. О. Линник, 2020 
МОСТИ ТА ТУНЕЛІ: ТЕОРІЯ, ДОСЛІДЖЕННЯ, ПРАКТИКА

Загальний вигляд регулюючого пристрою наведено на рис. 4. Застосування регулюючого пристрою призвело до необхідності модернізації існуючого типу плит безбаластного мостового полотна. Під час досліджень за основу взята плита типу БМП-КР, яка на відміну від плити БМП, передбачає використання у якості охоронних пристроїв контркутиків або контррейки типу Р50. Загальний вид плити БМП-КР 3 контркутиком наведено на рис. 5, а.

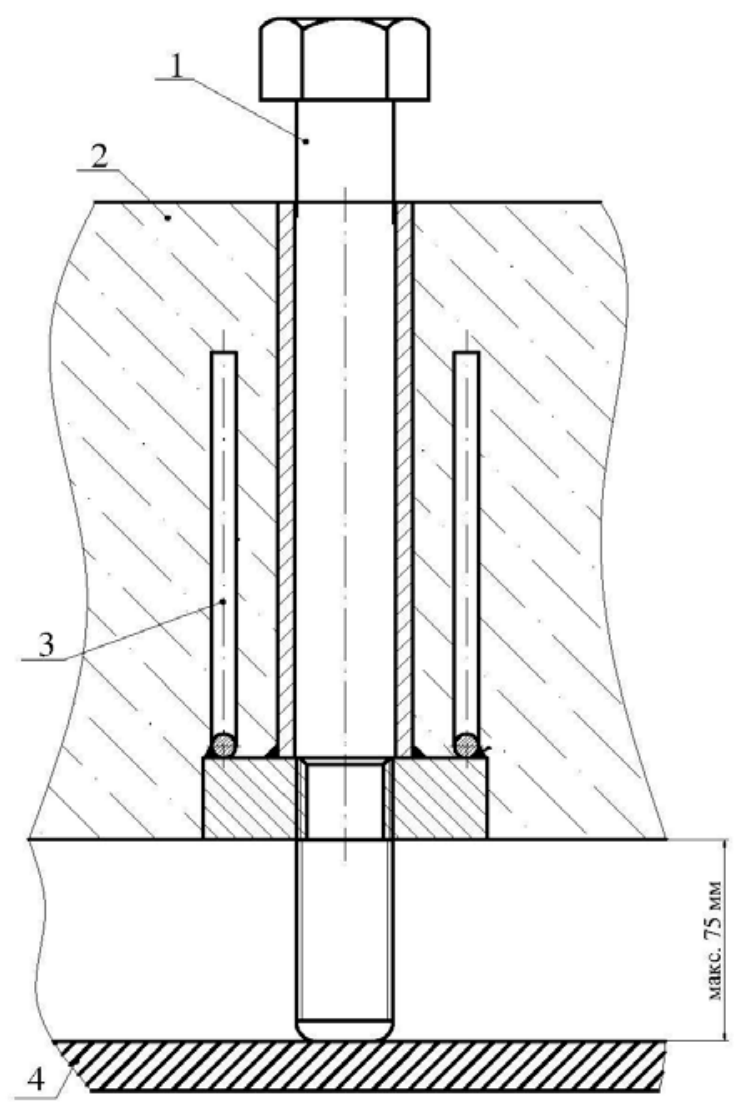

Рис. 4. Регулюючий пристрій:

1 - болт регулюючий типу БР; 2 - плита БМП;

3 - опора закладна; 4 - балка

Після виконання проєктних робіт щодо розміщення закладної деталі в тілі плити БМП-КР, була розроблена модернізована плита БМПКРм (далі - модернізована плита або зразок) (ДБН В.2.3-14:2006, 2006).

Загальний вид модернізованої плити наведено на рисунку 5, б. Кількість та розміщення регулюючих пристроїв на одній модернізованій плиті залежить від іiі типорозміру: від 4-х до 6ти.
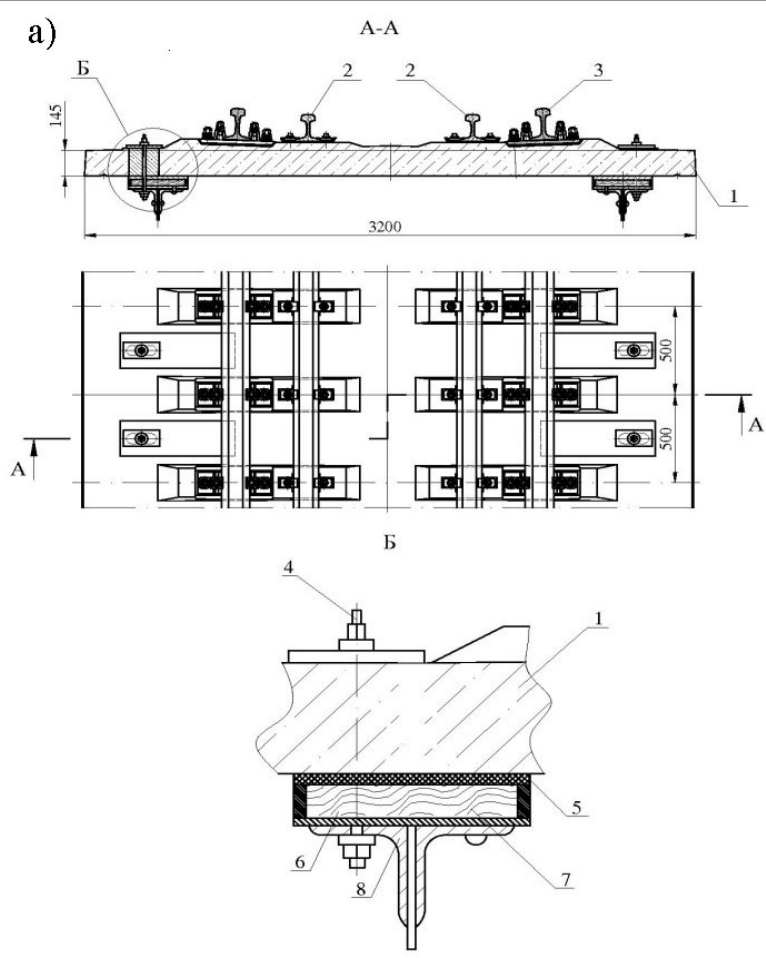

б)
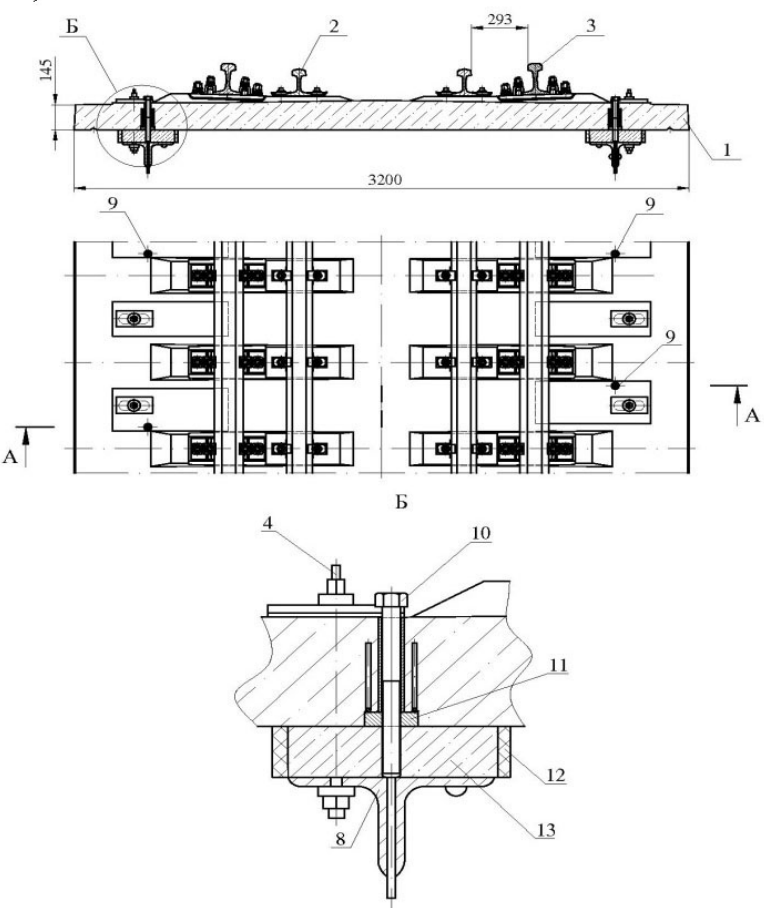

Рис. 5. Плита типу БМП-КР (а) та БМП-КРм (б): 1 - безбаластна залізобетонна плита; 2 - контркутик; 3 - рейка зі скріпленням; 4 - високоміцна шпилька кріплення плити; 5 - гума; 6 - дерев'яна опорна прокладка;

7 - прокладний шар; 8 - поздовжня балка; 9 - отвори під болти БР; 10 - болт типу БР; 11 - закладна деталь; 12 - незнімна опалубка зі спіненого поліетилену; 13 - прокладний шар MinobondHF

(c) С. М. Демченко, А. М. Курган, Г. О. Линник, 2020 


\section{Результати}

Для перевірки працездатності плит БМПКРм й регулюючих пристроїв були проведені лабораторні й заводські випробування.

Лабораторні випробування проводились на базі філії «Старокостянтинівський завод залізобетонних шпал» відповідно до програми та методики лабораторних випробувань У 7012.02.000 ПМ (2012).

Для лабораторних випробувань була розроблена схема (рис. 6, а) і побудований стенд (рис. 6, б), який дозволяє відповідно до вимог У 7012.02.000 ПМ (2012), здійснювати навантаження на плиту БМП-КРм, встановлену на регулюючі болти типу БР.

Випробування відбувались наступним чином. Плиту БМП-КРм було встановлено на випробувальний стенд. Плита опиралась на поздовжні балки через регулюючі болти, вкручені до упору, що забезпечувало максимальний зазор між плитою і поздовжньою балкою. Розрахункове навантаження на одну точку становило 120 кН
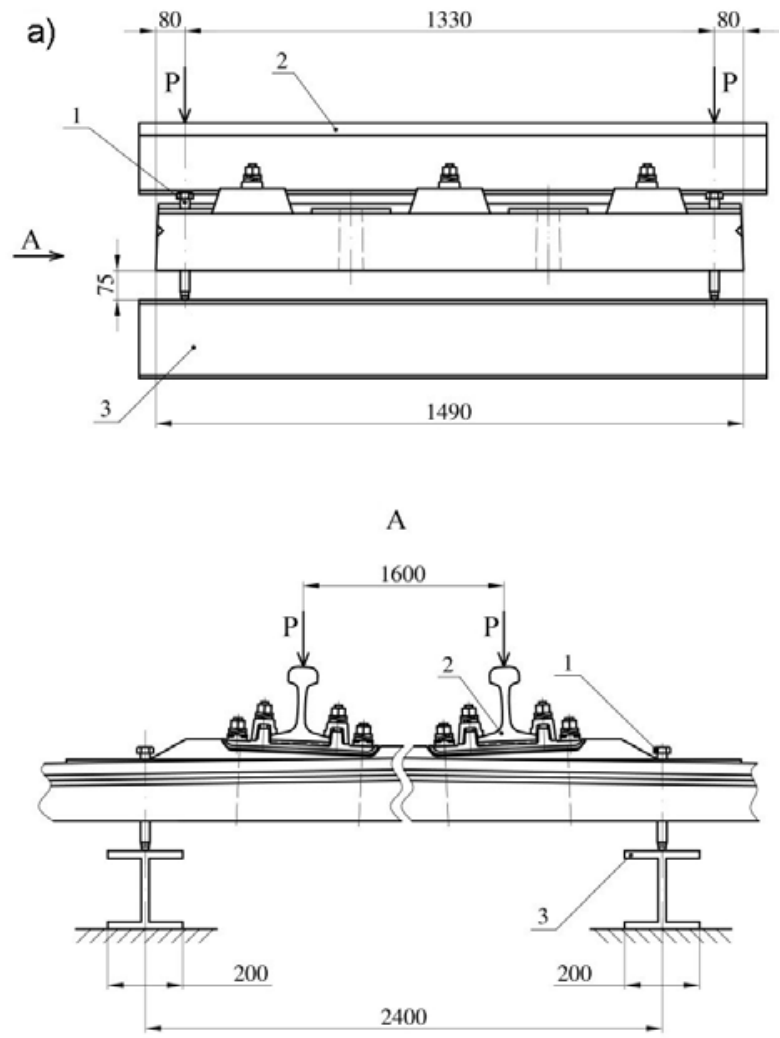

Рис. 6,а. Схема навантаження плити типу БМП-КРм: 1 - болт регулюючий, 2 - рейка типу Р65,

3 - металева балка; $\mathrm{P}$ - розрахункове навантаження б)

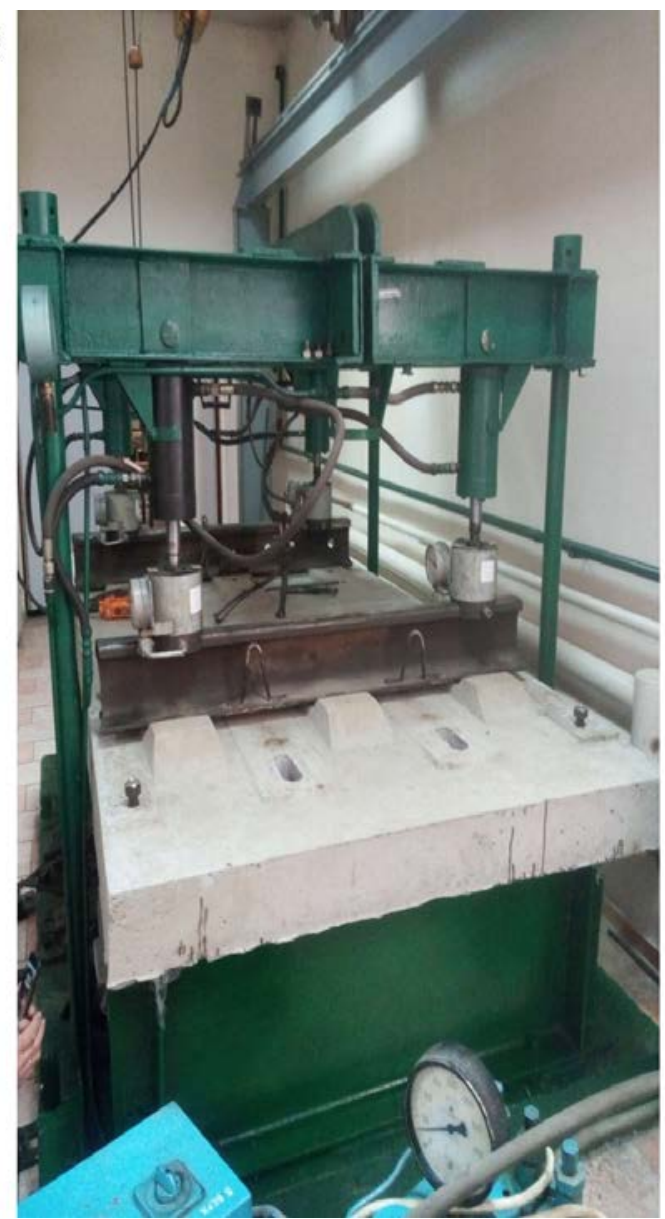

Рис. 6, б. Стенд для навантаження плити: 1 - болт регулюючий, 2 - рейка типу Р65, 3 - металева балка; Р - розрахункове навантаження

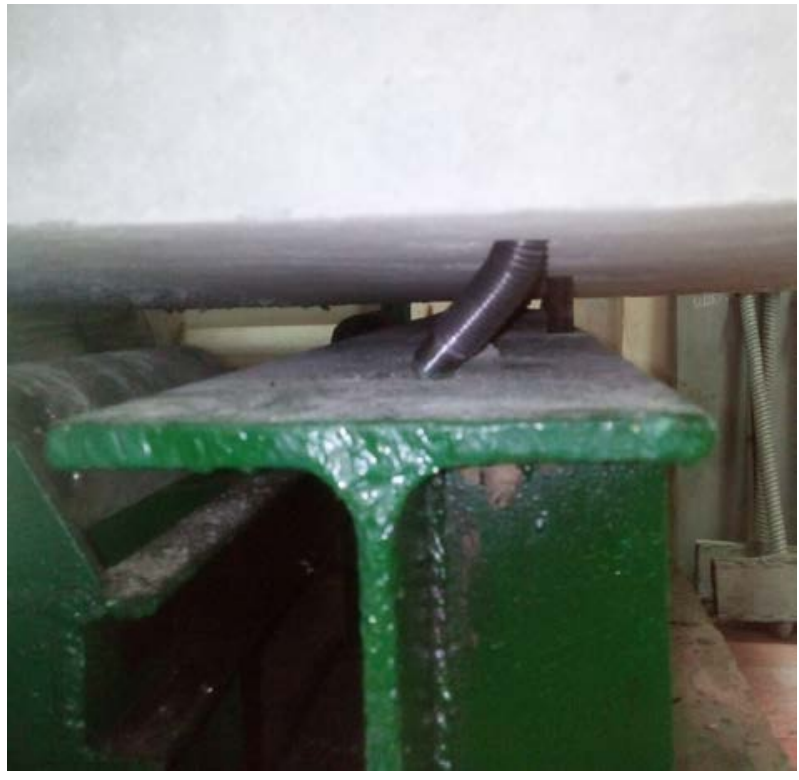

Рис. 7. Втрата стійкості високоміцних шпильок та болтів регулюючих типу БР 


\section{МОСТИ ТА ТУНЕЛІ: ТЕОРІЯ, ДОСЛІДЖЕННЯ, ПРАКТИКА}

Навантаження забезпечувалось гідравлічною системою і передавалось на плиту через змонтовані на плиті колійні рейки, прикладалось у двох точках на кожну рейку симетрично відносно поздовжньої вісі (рис. 6). Випробування проводились до руйнування. При навантажені 137 кН на одну точку сталась втрата стійкості регулюючих болтів типу БР (без руйнування бетону на поверхні плити, рис. 7).

\section{Використання незнімної опалубки та швид- котвердіючої безусадочної суміші замість прокладних брусів у взасмодії з болтами ре- гулюючими типу БР}

Конструкція опалубки, а найголовніше якісні характеристики прокладного шару впливають на вузол кріплення залізобетонних плит до стальної балки прогонової будови (Закора, Ключник, Линник, \& ін., 2011; Плугін, Мірошніченко, Забіяка, Линник, \& Бабенко, 2009), на можливість використовувати приварні шпильки під час організації робіт із заміни мостового полотна, коли час у «вікно» має обмеження.

Під час роботи були взяті до уваги результати натурних та чисельних досліджень напружено-деформованого стану шпильки кріплення плит мостового полотна з врахуванням різних типів прокладного шару, за якими величину навантаження, яке діє на приварну шпильку, можна суттєво зменшити шляхом збільшення жорсткості прокладного шару, тобто за допомогою застосування безусадочних швидкотвердіючих сумішей (Линник, 2010).

3 огляду на необхідність скорочення тривалості технологічних «вікон» на виконання робіт 3 монтажу плит БМП та забезпечення довговічності, міцності прокладного шару були визначені наступні технічні вимоги до швидкотвердіючої безусадочної суміші: міцність на стиск через 2 години не менше 8 МПа; міцність на стиск через 24 години - 20 МПа; міцність на стиск через 28 діб - 60 МПа; усадка через 56 діб $<0,1 \%$; термін служби не менше 40 років; бути водонепроникним; морозостійкість не менше F 200; відповідати вимогам 3 тріщиностійкості на протязі всього строку експлуатації. При проведенні випробувань використовувались полімерцементні розчини Minotop 60, Minobond, Minobond HF, які заливались в зазор між плитою і поздовжньою балкою через отво- ри для високоміцних шпильок - (рисунок 9). Крім того, при проведенні лабораторних випробувань визначалась можливість використання незнімної опалубки зі спіненого поліетилену, товщиною $\mathrm{B}_{\min }=160$ мм (рис. 8).

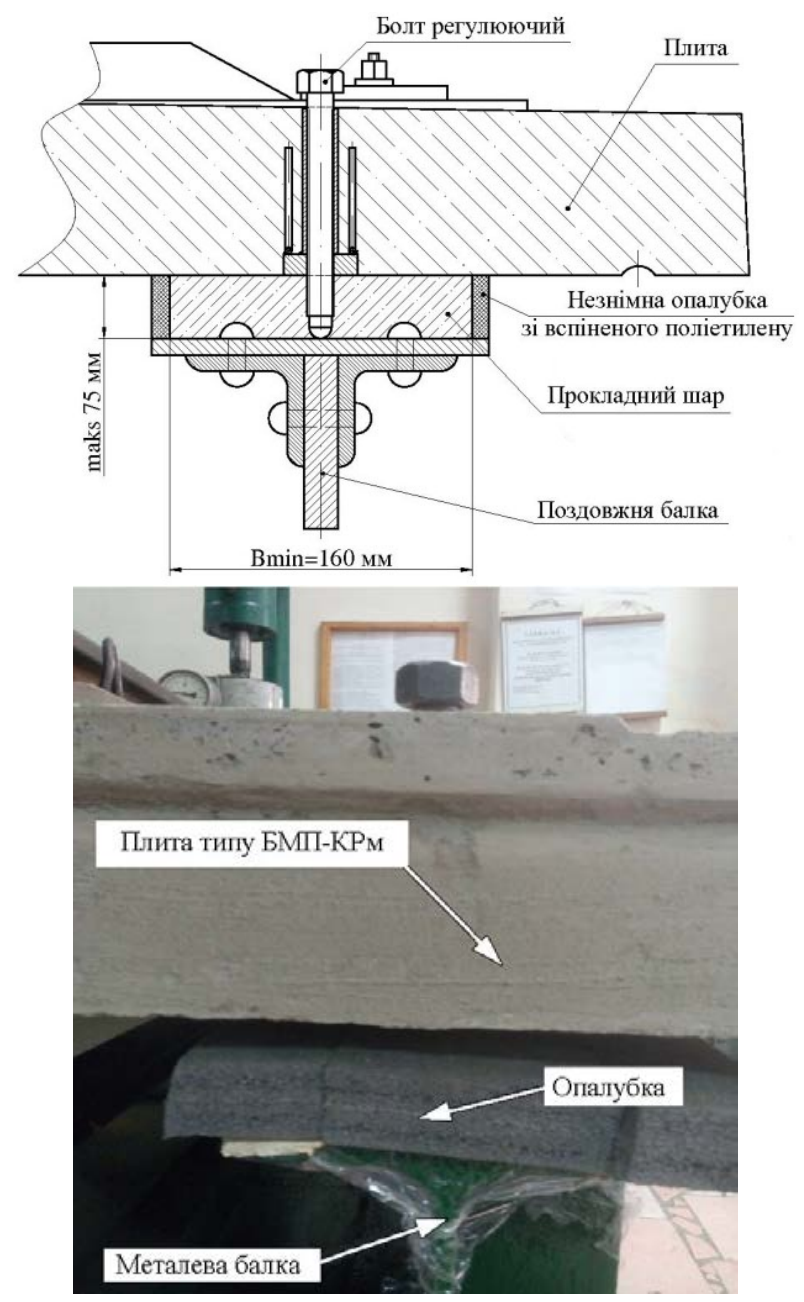

Рис. 8. Незнімна опалубка

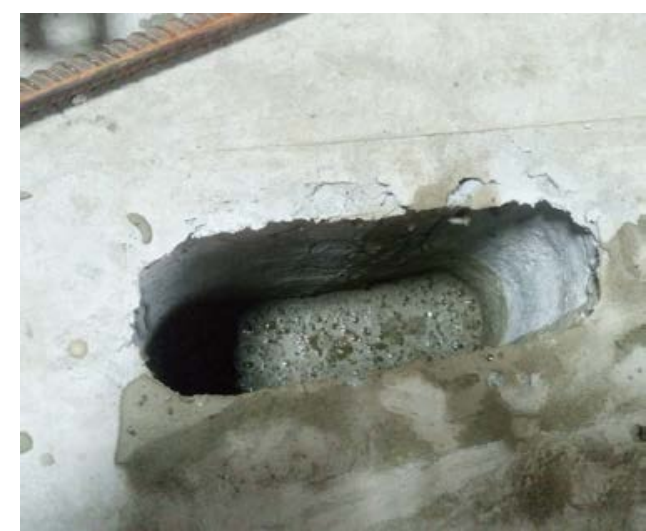

Рис. 9. Заливка швидкотвердіючої безусадочної суміші під час лабораторних випробувань

(c) С. М. Демченко, А. М. Курган, Г. О. Линник, 2020 
МОСТИ ТА ТУНЕЛІ: ТЕОРІЯ, ДОСЛІДЖЕННЯ, ПРАКТИКА

За результатами випробувань оптимальним для використання визначено полімерцементний розчин - Minobond HF, який протягом 2-х годин набрав міцність 7,6 МПа при температурі навколишнього середовища $+14^{\circ}$, що практично відповідає нормативній міцності -8 МПа при температурі навколишнього середовища $+30^{\circ}$

\section{Наукова новизна та практична значимість}

Таким чином, заводські випробування проведені згідно з У 7012.02.000 ПМ1 (2012), підтвердили відповідність дослідних зразків плит виробництва філії «Старокостянтинівський завод залізобетонних шпал» типу БМП-КРм 3 елементами регулювання їх проєктного положення вимогам конструкторської та технічної документації.

\section{Висновки}

1. Вузол регулювання положення в профілі плит безбаластного постового полотна витримав лабораторні та заводські випробування i забезпечує регулювання товщини прокладного шару до 75 мм.

2. Незнімна опалубка з спіненого поліетилену забезпечує влаштування прокладного шару товщиною $25 \ldots 75$ мм, надійно утримує швидкотвердіючу безусадочну суміш Minobond HF під час заливки та набору міцності.

3. Застосування плит БМП-КРм разом 3 незнімною опалубкою 3 спіненого поліетилену значно скорочує трудовитрати 3 влаштування безбаластного мостового полотна на залізобетонних плита а використання у якості прокладного шару швидкотвердіючої безусадочної суміші Minobond-HF дозволяе виключити 3 конструкції мостового полотна недовговічні елементи 3 деревини, забезпечити проєктний термін експлуатації прокладного шару рівний проєктному терміну експлуатації плит.

4. Результати лабораторних та заводських випробувань доцільно врахувати при розробці рекомендацій щодо удосконалення технології укладання безбаластного мостового полотна із застосуванням елементів регулювання проєктного положення плит.

5. Для остаточної розробки конструкції мостового полотна на залізобетонних плитах типу БМП-КРм 3 застосуванням регулюючих пристроїв та технології їх укладання доцільно про- вести їх дослідні експлуатаційні випробування та дослідну експлуатацію.

\section{СПИСОК ВИКОРИСТАНИХ ДЖЕРЕЛ}

Marochka, V. V., \& Boboshko, S. H. (2018). Analysis of the problems of sections with the transitional rigidity indicator in world bridging. Мости ma myнелі: теорія, дослідження, практика, 16, 82-92.

ГОСТ 1050-2013 (2013). Металлопродукция из нелегированных конструкционных качественных и специальных сталей. Общие технические условия (с поправкой). Москва: Межгосударственный совет по стандартизации, метрологии и сертификации.

ДБН В.2.3-14:2006 (2006). Споруди транспорту. Мости та труби. Правила проектування. Київ: Мін.буд., архіт. та житл.-комун. госп-ва.

Закора, О. Л., Ключник, С. В., Линник, Г. О. \& ін. (2011). Напружено-деформований стан залізобетонної плити безбаластного мостового полотна. Вісн. Дніпропетр. наи. ун-ту залізн. трансп. ім. акад. В. Лазаряна, 39, 47-50.

Ключник, С. В. (2017). Аналіз сучасного стану металевих прогонових будов. Мости та тунелі: теорія, дослідження, практика, 29-40.

Линник, Г. О. (2010). Дослідження місцевих деформацій бетонного прокладного шару при використання мостового полотна на плитах БМП. Теорія і практика будівниџтва, 293-296.

Марочка, В. В., \& Бобошко, С. Г. (2018). Современные методы реконструкции мостовых сооружений. Мости та тунелі: теорія, дослідження, практика, 14, 15-21.

Плугін, А. А., Мірошніченко, С. В., Забіяка, О. А., Линник, Г. О., \& Бабенко, А. І. (2009). Систематизація пошкоджень залізобетонних плит безбалластного мостового полотна залізничних мостів. 3б. наук. пращь УкрДАЗТ, 109, 120-130.

у 7012.02.000 ПМ (2012). Плити залізобетонні безбаластного мостового полотна залізничних мостів 3 елементами регулювання ї проектного положення. Програма та методика лабораторних випробувань дослідних зразків : Дніпропетровськ: СП «ДНКТБ КГ» філії «НДКТІ» ПАТ «Укрзалізниця».

У 7012.02.000 ПМ1 (2012). Плити залізобетонні безбаластного мостового полотна залізничних мостів $з$ елементами регулювання їх проектного положення. Програма та методика попередніх (заводських) випробувань дослідної партії : Дніпропетровськ: СП «ДНКТБ КГ» філії «НДКТІ» ПАТ «Укрзалізниця».

ЦП-0137 (2006). Інструкція з укладання та експлуатації безбаластного мостового полотна (БМП) на залізобетонних плитах. Харків: УкрДАЗТ. 


\author{
С. Н. ДЕМЧЕНКО ${ }^{1}$, А. Н. КУРГАН ${ }^{2}$, Г. О. ЛИННИК $3^{3 *}$ \\ ${ }^{1}$ Структурное подразделение «Днепровское научно-конструкторское технологическое бюро путевого хозяйства» \\ филиала «Научно-исследовательский и конструкторско-технологический институт железнодорожного транспорта» \\ АО «Укрзализныця», пл. Вокзальная 11-Ж., Днепр, Украина, 49000, тел. +38 (056) 79323 60, \\ эл. почта s.demchenko@dp.uz.gov.ua \\ ${ }^{2}$ Структурное подразделение «Днепровское научно-конструкторское технологическое бюро путевого хозяйства» \\ филиала «Научно-исследовательский и конструкторско-технологический институт железнодорожного транспорта» \\ АО «Укрзализныця», пл. Вокзальная 11-Ж., Днепр, Украина, 49000, тел. +38 (056) 79323 47, \\ эл. почта a.kurgan@dp.uz.gov.ua \\ 3* Департамент пути и сооружений АО «Укрзализныця», ул. Е. Гедройца, 5, г. Киев, Украина, 03150, \\ тел. +38 (044) 46503 54, эл почта georgiylinnik@gmail.com
}

\title{
УСОВЕРШЕНСТВОВАНИЕ ТЕХНОЛОГИИ УКЛАДКИ БЕЗБАЛЛАСТНОГО МОСТОВОГО ПОЛОТНА НА ЖЕЛЕЗНОДОРОЖНЫХ МОСТАХ
}

Цель. Совершенствование технологии укладки безбалластного мостового полотна на плитах БМП путем замены деревянных прокладок на быстротвердеющие высокопрочные подливные смеси с установкой плит в проектное положение с использованием специальных регулирующих устройств. Методика. Предложенное авторами регулирующее устройство, состоящее из болта типа БР и закладной детали, которая входит в состав плиты безбалластного мостового полотна. Устройство обеспечивает установление плиты БМП в проектное положение по вертикали с точностью \pm 1 мм и выдерживает нагрузку от собственного веса и подвижного состава, применяющегося при заключении и рихтовки мостового полотна. Для лабораторных испытаний была разработана схема и построен стенд, который позволяет в соответствии с требованиями У 7012.02.000 ПМ (2012), осуществлять нагрузку на плиту БМП-КРм, установленную на регулирующие болты типа БР. Нагрузка обеспечивалась гидравлической системой и передавалась на плиту через смонтированные на плите путевые рельсы, прикладывалась в двух точках на каждый рельс симметрично относительно продольной оси. Испытания проводились до разрушения. Результаты. При нагрузке 137 кН на одну точку произошла потеря устойчивости регулирующих болтов типа БР. Использована несъемная опалубка и быстротвердеющая безусадочная смесь вместо прокладочных брусьев во взаимодействии с болтами регулирующими типа БР. Научная новизна. Она заключается в получении зависимостей усилий от конструкции БМП. Практическая значимость. Подтверждено соответствие опытных образцов плит типа БМП-КРм с элементами регулирования их проектных положение требованиям конструкторской и технической документации.

Ключевые слова: безбалластное мостовое полотно; болт регулирующий; регулирующее устройство; шпилька высокопрочная; прокладочный слой; быстротвердеющая смесь; испытания

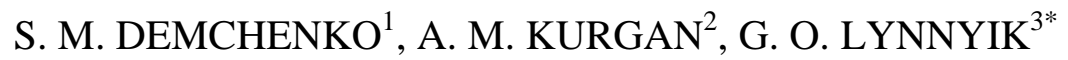 \\ ${ }^{1}$ Subdivision “Dnipro Research and Design Technological Bureau of Railway Economy” branch of the Research and Design \\ Institute of Railway Transport of JSC Ukrzaliznytsia, pl. Station, 11-Ж, Dnepr, Ukraine, 49000, tel. +38 (056) 7932360 , \\ e-mail s.demchenko@dp.uz.gov.ua \\ ${ }^{2}$ Subdivision "Dnipro Research and Design Technological Bureau of Railway Economy” branch of the Research and Design \\ Institute of Railway Transport of JSC Ukrzaliznytsia, pl. Station, 11-Ж, м. Dnepr, Ukraine, 49000, tel. +38 (056) 79323 47, \\ e-mail a.kurgan@dp.uz.gov.ua \\ ${ }^{3 *}$ Department of Tracks and Structures of JSC "Ukrzaliznytsia", st. E. Giedroyc, 5, Kyiv, Ukraine, 03150, \\ tel. +38 (044) 46503 54, e-mail georgiylinnik@gmail.com
}

\section{IMPROVEMENT OF LAYING TECHNOLOGY OF BALLASTLESS BRIDGE DECK ON RAILWAY BRIDGES}

Purpose. Improvement of the technology of laying a ballastless bridge deck on BMP slabs by replacing wooden gaskets with fast-hardening high-strength pouring mixtures with the installation of the slabs in the design position 
using special control devices. Methodology. A regulating device proposed by the authors, consisting of a BR-type bolt and an embedded part, which is part of the slab of a ballastless bridge deck. The device ensures the installation of the BMP slab in the design position vertically with an accuracy of $\pm 1 \mathrm{~mm}$ and withstands the load from its own weight and the rolling stock used in the laying and straightening of the bridge deck. For laboratory tests, a scheme was developed and a stand was built, which allows, in accordance with the requirements of U 7012.02.000 PM (2012), to carry out the load on the BMP-KRm plate installed on the regulating bolts of the BR type. The load was provided by a hydraulic system and transmitted to the plate through track rails mounted on the plate, applied at two points on each rail symmetrically about the longitudinal axis. The tests were carried out until failure. Results. With a load of $137 \mathrm{kN}$ per point, there was a loss of stability of control bolts of the BR type. A fixed formwork and a fasthardening non-shrinking mixture were used instead of spacers in cooperation with regulating bolts of the BR type. Originality. It consists of obtaining the dependences of forces on the design of the BMP. Practical value. The accordance of prototypes of plates of the BMP-KRm type with elements of regulation of their design position to the requirements of design and technical documentation was confirmed.

Keywords: ballastless bridge deck; control bolt; regulating device; high-strength hairpin; interlayer; fast hardening mixture; trials

\section{REFERENCES}

Marochka, V. V., \& Boboshko, S. H. (2018). Analysis of the problems of sections with the transitional rigidity indicator in world bridging. Мости та тунелі: теорія, дослідження, практика, 16, 82-92. (in English)

GOST 1050-2013 (2013). Metalloproduktsiya iz nelegirovannykh konstruktsionnykh kachestvennykh i spetsialnykh staley. Obshchie tekhnicheskie usloviya (s popravkoy). Moskva: Mezhgosudarstvennyy sovet po standartizatsii, metrologii i sertifikatsii. (in Russian)

DBN V.2.3-14:2006 (2006). Sporudy transportu. Mosty ta truby. Pravyla proektuvannia. Kyiv: Min.bud., arkhit. ta zhytl.-komun. hosp-va. (in Ukrainian)

Zakora, O. L., Kliuchnyk, S. V., Lynnyk, H. O. \& in. (2011). Napruzheno-deformovanyi stan zalizobetonnoi plyty bezbalastnoho mostovoho polotna. Visn. Dnipropetr. nats. un-tu zalizn. transp. im. akad. V. Lazariana, 39, 47-50. (in Ukrainian)

Kliuchnyk, S. V. (2017). Analiz suchasnoho stanu metalevykh prohonovykh budov. Mosty ta tuneli: teoriia, doslidzhennia, praktyka, 29-40. (in Ukrainian)

Lynnyk, H. O. (2010). Doslidzhennia mistsevykh deformatsii betonnoho prokladnoho sharu pry vykorystannia mostovoho polotna na plytakh BMP. Teoriia i praktyka budivnytstva, 293-296. (in Ukrainian)

Marochka, V. V., \& Boboshko, S. G. (2018). Sovremennye metody rekonstruktsii mostovykh sooruzheniy. Mosty ta tuneli: teoriia, doslidzhennia, praktyka, 14, 15-21. (in Russian)

Pluhin, A. A., Miroshnichenko, S. V., Zabiiaka, O. A., Lynnyk, H. O., \& Babenko, A. I. (2009). Systematyzatsiia poshkodzhen zalizobetonnykh plyt bezballastnoho mostovoho polotna zaliznychnykh mostiv. Zb. nauk. prats UkrDAZT, 109, 120-130. (in Ukrainian)

U 7012.02.000 PM (2012). Plyty zalizobetonni bezbalastnoho mostovoho polotna zaliznychnykh mostiv z elementamy rehuliuvannia yikh proektnoho polozhennia. Prohrama ta metodyka laboratornykh vyprobuvan doslidnykh zrazkiv : Dnipropetrovsk: SP «DNKTB KH» filii «NDKTI» PAT «Ukrzaliznytsia». (in Ukrainian)

U 7012.02.000 PM1 (2012). Plyty zalizobetonni bezbalastnoho mostovoho polotna zaliznychnykh mostiv z elementamy rehuliuvannia yikh proektnoho polozhennia. Prohrama ta metodyka poperednikh (zavodskykh) vyprobuvan doslidnoi partii : Dnipropetrovsk: SP «DNKTB KH» filii «NDKTI» PAT «Ukrzaliznytsia». (in Ukrainian) TsP-0137 (2006). Instruktsiia z ukladannia ta ekspluatatsii bezbalastnoho mostovoho polotna (BMP) na zalizobetonnykh plytakh. Kharkiv: UkrDAZT. (in Ukrainian)

Надійшла до редколегії 11.09.2020.

Прийнята до друку 26.10.2020. 